\title{
Role of Protein Synthesis in the Cell Division and Starvation Induced Resistance to Autolysis of a Marine Vibrio during the Initial Phase of Starvation
}

\author{
By THOMAS NYSTRÖM* AND STAFFAN KJELLEBERG \\ Department of Marine Microbiology, University of Göteborg, Carl Skottsbergs Gata 22, \\ S-413 19 Sweden
}

(Received 21 September 1988; revised 18 January 1989; accepted 30 January 1989)

\begin{abstract}
Starvation of a marine Vibrio sp. S14 for carbon, nitrogen and phosphorus resulted in a fourfold increase in cell number during the first $6 \mathrm{~h}$ in the starvation regime. This initial cell division of non-growing cells was dependent on both DNA and peptidoglycan synthesis as deduced from inhibition experiments using nalidixic acid and ampicillin. Inhibition of protein synthesis by the addition of chloramphenicol led to the cessation of both cell division and DNA synthesis after 40-60 $\mathrm{min}$ in the starvation regime. Starvation also induced resistance against autolytic cell wall degradation. Resistance to ampicillin-induced murein degradation was most extensive in the portion of the cell wall that was synthesized after the onset of starvation and was dependent on de novo protein synthesis. The amount of $\mathrm{D}$-alanine per unit dry weight increased twofold during $24 \mathrm{~h}$ of starvation and an increased resistance to lysis induced by sonication was observed during this period. It is suggested that the fourfold increase in cell number during the first six hours of starvation requires proteins synthesized de novo and that new rounds of DNA replication may be initiated during non-growth subsequent to $40-60 \mathrm{~min}$ of starvation. While the rate of DNA synthesis during the initial 40-60 min was unaffected by the blockage of protein synthesis, the mechanism conferring autolysis resistance was effectively inhibited.
\end{abstract}

\section{INTRODUCTION}

Bacteria in natural habitats frequently undergo periods of growth and non-growth, and longterm survival of energy and nutrient depleted marine bacteria is well documented (Morita, 1985). The strain used in this study, the marine Vibrio sp. S14 has previously been shown to adapt to non-growth conditions by extensive morphological and physiological rearrangements (Mårdén et al., 1985; Malmcrona-Friberg et al., 1986; Nyström et al., 1986) including a sequential induction of starvation-specific proteins and an increased rate of proteolysis (Nyström et al., 1988).

Bacterial cells may respond to energy and/or nutrient exhaustion by fragmentation (Novitsky \& Morita, 1977; Morita, 1985), i.e. division without growth. The role of DNA synthesis during the fragmentation process of S14 cells has previously been demonstrated (Mårdén et al., 1988; Nyström \& Kjelleberg, 1987) and constitutes a marked distinction between this isolate and the fragmentation process of the psychrophilic marine Vibrio sp. Ant 300 (Novitsky \& Morita, 1977). These authors suggested that the increase in cell number was related to the number of nuclear bodies per cell of the growing culture entering the starvation regime and suggested that DNA synthesis was not required for the initial fragmentation process. The role of peptidoglycan synthesis during this process is also poorly investigated in marine vibrios. Non-growing stringent cells of Escherichia coli that are deprived of amino acids continue to produce peptidoglycan at a rate approximately $30 \%$ of that of growing cells (Tuomanen $\&$ Tomasz, 1986). An important factor in the survival capacity of non-growing bacteria is their resistance to

\footnotetext{
Abbreviations: Ap, ampicillin; Cm, chloramphenicol; GlcNAc, $N$-acetyl-D-glucosamine; NSS, nine salt
} solution; Nx, nalidixic acid; dThd, thymidine; $V_{u}$, theoretical minimal cell volume. 
both autolytic and heterolytic processes and, unless relaxation of the stringent response is achieved, amino-acid-deprived $E$. coli cells rapidly develop resistance to autolysis induced by a variety of agents (Kusser \& Ishiguro, 1985). Tuomanen et al. (1988) suggested that part of the lysis resistance that developed during non-growth was related to the deposition of anomalous and resistant peptidoglycan at some strategically located sites in the murein sacculus. Another factor that may add to the maintenance of cell wall integrity is the degradation or decreased activity of the murein hydrolases.

In addition to the presence of a sequential induction of starvation proteins by Vibrio sp. S14 (Nyström et al., 1988), it has also been demonstrated that the inhibition of protein synthesis during the first hours of starvation greatly compromised survival during prolonged starvation. The present study deals with the role of protein synthesis in DNA replication, peptidoglycan synthesis and cell division during the initial phase of non-growth of the marine Vibrio sp. S14. In this context we also investigated the role of proteins synthesized during starvation for the development of autolysis resistance.

\section{METHODS}

Cultivation and starvation conditions. The marine Vibrio S14 (CCUG 15956) used in this study is described by Mårdén et al. (1987). S14 was grown on MNSS minimal medium (Nyström et al., 1989) supplemented with 2.0 g casamino acids per litre. A nine salt solution (NSS) was used for washing the bacteria and in the starvation regime (Nyström et al., 1986). Cells were cultured at $26^{\circ} \mathrm{C}$ on a rotary shaker $(320$ r.p.m.) and harvested in exponential phase $\left(1 \times 10^{8}\right.$ cells ml $\left.{ }^{-1}\right)$ by centrifugation $(8000 \mathrm{~g}, 6 \mathrm{~min}$ ), or filtration (Millipore $0.45 \mu \mathrm{m}$ ), washed once and resuspended in NSS. S14 cultures in MNSS media were in balanced growth at a growth rate of 1.8 doublings $\mathrm{h}^{-1}$. Starvation regimes were kept at $26^{\circ} \mathrm{C}$ for $24 \mathrm{~h}$.

Bacterial cell counts and cell volumes. Total counts and size distributions were obtained using a microcomputerized Elzone ADC-80XY particle counter, with a $12 \mu \mathrm{m}$ orifice tube and chart recorder. The particle counter was operated with NSS as both the internal fluid and diluent.

Determination of DNA and peptidoglycan synthesis. The rates of macromolecular synthesis per biovolume were determined by pulse-labelling ( 2 and $4 \mathrm{~min})$, using $\left[\right.$ methyl $\left.{ }^{3}{ }^{3} \mathrm{H}\right]$ thymidine $\left(\left[{ }^{3} \mathrm{H}\right] \mathrm{dThd}\right)\left(0.3 \mu \mathrm{g} \mathrm{ml}{ }^{-1} ; 4.66 \mathrm{TBq}\right.$ mmol $^{-1}$; Amersham) to label DNA and $N$-acetyl-D- $\left[{ }^{3} \mathrm{H}\right]$ glucosamine (GlcNAc) $\left(1.9 \mu \mathrm{g} \mathrm{ml}^{-1} ; 218 \mathrm{GBq} \mathrm{mmol}^{-1}\right.$; Amersham) to label peptidoglycan. The rate of incorporation was determined by assessing the amount of radioactivity precipitable in cold $5 \%(\mathrm{w} / \mathrm{v})$ trichloroacetic acid (for DNA) or in boiling $5 \%$ sodium dodecyl sulphate (for peptidoglycan). The labelled dThd that was incorporated by the cells was also examined for resistance to alkaline hydrolysis.

After incubation for $1 \mathrm{~h}$ at $0{ }^{\circ} \mathrm{C}$, samples $(200 \mu \mathrm{l})$ were collected on membrane filters as previously described (Nyström et al., 1986). The radioactivity on the filters was determined in a liquid scintillation counter with Aquassure (New England Nuclear) as scintillation fluid.

Murein degradation. The murein was radioactively labelled for $30 \mathrm{~min}$ during growth in exponential phase or during the first hour of starvation. Following this protocol, equal amounts of radiolabel in the murein of the growing and non-growing cells were obtained (20000 c.p.m. per $10^{8}$ cells, \pm 1500 c.p.m.). The effect of ampicillin (Ap) $\left(50 \mu \mathrm{g} \mathrm{ml}^{-1}\right)$ on the rate of murein hydrolysis was then determined according to Goodell \& Tomasz (1980). The percentage of undigested murein was plotted against the time of incubation with Ap.

Cell disruption by sonication. Starvation-induced resistance to sonication was determined using an MSE Soniprep 150. The number of intact non-lysed cells was plotted against the number of ultra-sound pulses $(5 \mathrm{~s}$, $8 \mu \mathrm{m})$. The effect of sonication on $0,1,5$ and $24 \mathrm{~h}$ starved cells was examined.

Inhibition of DNA, protein and peptidoglycan synthesis. The inhibitory effect of each of the antibiotics used (nalidixic acid, Nx; chloramphenicol, $\mathrm{Cm}$; ampicillin, Ap) was determined by comparison of the rate of incorporation of $\left[{ }^{3} \mathrm{H}\right] \mathrm{d}$ Thd, $\left[{ }^{3} \mathrm{H}\right]$ leucine or $\left[{ }^{3} \mathrm{H}\right] \mathrm{GlcNAc}$ into non-treated cells with the rate of incorporation into antibiotic-treated cells. The concentrations used in this study $\left(\mathrm{Nx}, \mathrm{Cm}\right.$, and $\mathrm{Ap} ; 200,100$ and $50 \mathrm{\mu g} \mathrm{ml}^{-1}$, respectively) inhibited the target macromolecular synthesis by $96-99 \%$. The antibiotics were purchased from Sigma.

Reproducibility. Each experiment was repeated at least twice to confirm reproducibility. Representative results are presented in the figures of this paper.

\section{RESULTS}

\section{Fragmentation of $\mathrm{S} 14$ cells}

The relative changes in the total counts during the initial $6 \mathrm{~h}$ of starvation of untreated and antibiotic-treated cells are depicted in Fig. 1. Nx and Ap completely prevented the fourfold 


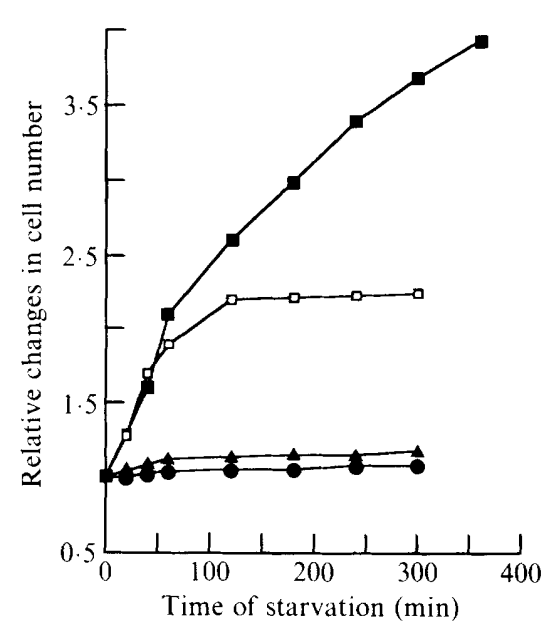

Fig. 1

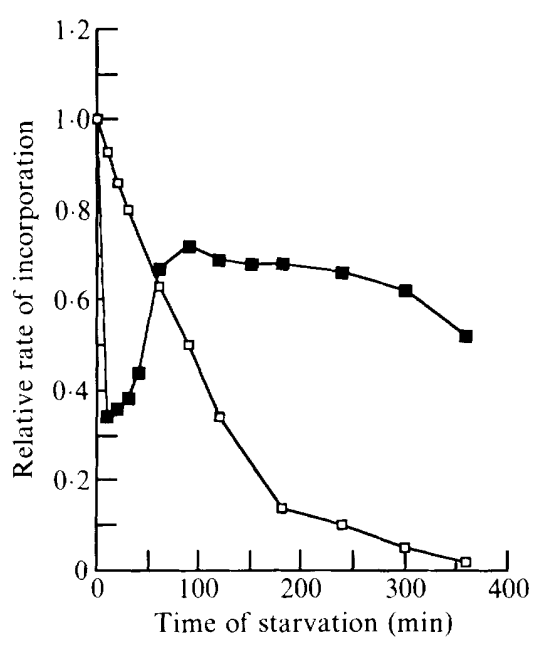

Fig. 2

Fig. 1. Effect of starvation on the cell number of non-treated ( $\square$ ), nalidixic acid- (O), ampicillin- $(\mathbf{A})$ and chloramphenicol-treated $(\square)$ starvation regimes of S14. The cell numbers were related to that obtained at the onset of starvation.

Fig. 2. The relative rates of DNA ( $\square$ ) and peptidoglycan ( $\square$ ) synthesis during the initial phase of starvation. The relative rates of synthesis were related to the rate obtained for exponentially growing cells, which was assigned a value of 1.0.

increase in cell number typical of the starvation response of these cells. The median cell volume in the control culture was $2.3 \mu \mathrm{m}^{3}$ at the onset of starvation and decreased to $1.1 \mu \mathrm{m}^{3}$ after the first doubling $(60 \mathrm{~min})$. No detectable changes in cell number were seen after $6 \mathrm{~h}$, at which time the median cell volume was $0.52 \mu \mathrm{m}^{3}$ and the total counts had increased fourfold. The rate of DNA synthesis declined steadily throughout the starvation period studied. After $6 \mathrm{~h}$ the rate of incorporation of $\left[{ }^{3} \mathrm{H}\right] \mathrm{dTh}$ was approximately $2 \%$ of the rate obtained for exponentially growing cells (Fig. 2). A different kinetic pattern was observed for the incorporation of $\left[{ }^{3} \mathrm{H}\right]$ GlcNAc. The rate of peptidoglycan synthesis decreased rapidly during the first $10 \mathrm{~min}$ of starvation to approximately $30 \%$, then a relatively high rate of synthesis $(50-70 \%)$ was restored and maintained throughout the fragmentation process (Fig. 2). Inhibition of protein synthesis by the addition of $\mathrm{Cm}$ had no effect on fragmentation during the first 40-60 min (Fig. 1). After this time, however, both cell division (Fig. 1) and DNA synthesis (Fig. 3) ceased as a result of the addition of $\mathrm{Cm}$. S14 remained $100 \%$ viable throughout the period of $\mathrm{Cm}$ exposure $(5 \mathrm{~h})$. The rate of GlcNAc incorporation was not inhibited in $\mathrm{Cm}$-treated cells during this period (data not shown), indicating that the discontinued division in $\mathrm{Cm}$-treated cells was due to an impaired potential to replicate rather than to synthesize murein.

\section{Ampicillin-induced lysis during growth and non-growth}

Addition of $50 \mu \mathrm{g}$ Ap to growing S14 cells caused a rapid decrease in culture viability (Fig. 4) and pronounced effects on the shape and integrity of the cells (Fig. $5 a$ ). Large bulges localized at the equatorial area of the cells were observed in Ap-treated growing cells. Starved cells, however, rapidly showed resistance against the lytic and bactericidal effects of Ap (Fig. 4) and no visible effects on the integrity of the cell wall were observed (Fig. $5 b$ ). The effect of starvation on the Ap-induced autolysis was also examined by measuring the solubilization of prelabelled peptidoglycan. As depicted in Fig. 6(a), the addition of $\mathrm{Cm}$ to carbon and nutrient deprived cultures abolished the resistance to Ap. Duplicate portions were radiolabelled for $1 \mathrm{~h}$ in the starvation regime, one set with the addition of $\mathrm{Cm}\left(100 \mu \mathrm{g} \mathrm{ml}^{-1}\right)$ and the other as the control culture. After $1 \mathrm{~h}$, cells were washed and resuspended in starvation regimes containing Ap and 


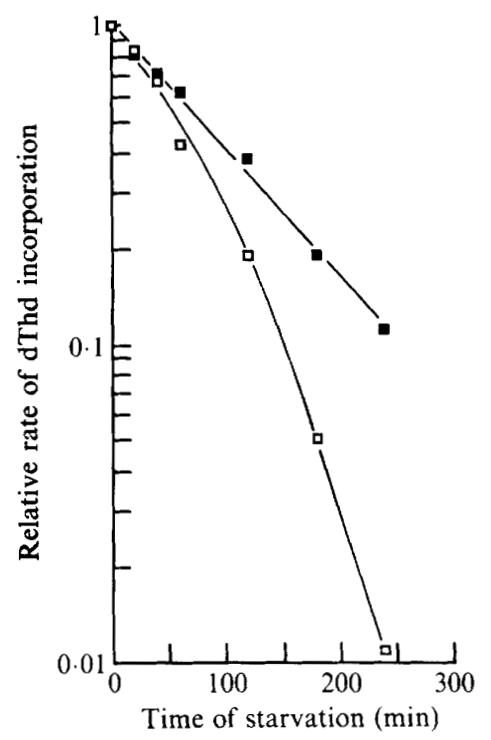

Fig. 3

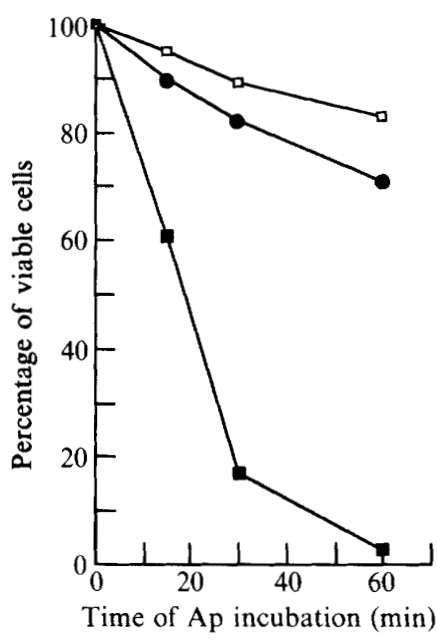

Fig. 4

Fig. 3. Relative rates of DNA synthesis in non-treated $(\square)$ and chloramphenicol-treated $(\square)$ S14 cells during the initial phase of starvation. The S14 culture was divided into two portions immediately at the onset of starvation. One portion served as the control (non-treated) and the other portion was incubated with chloramphenicol. The relative rates of synthesis were related to the rate of non-treated cells at the onset of starvation $(0 \mathrm{~min})$.

Fig. 4. Effect of ampicillin on the viability of growing ( $\square$ ), $30 \mathrm{~min}$ pre-starved (O) and $60 \mathrm{~min}$ prestarved $(\square)$ cells. Viability was assessed by determining c.f.u. using the spread plate technique.
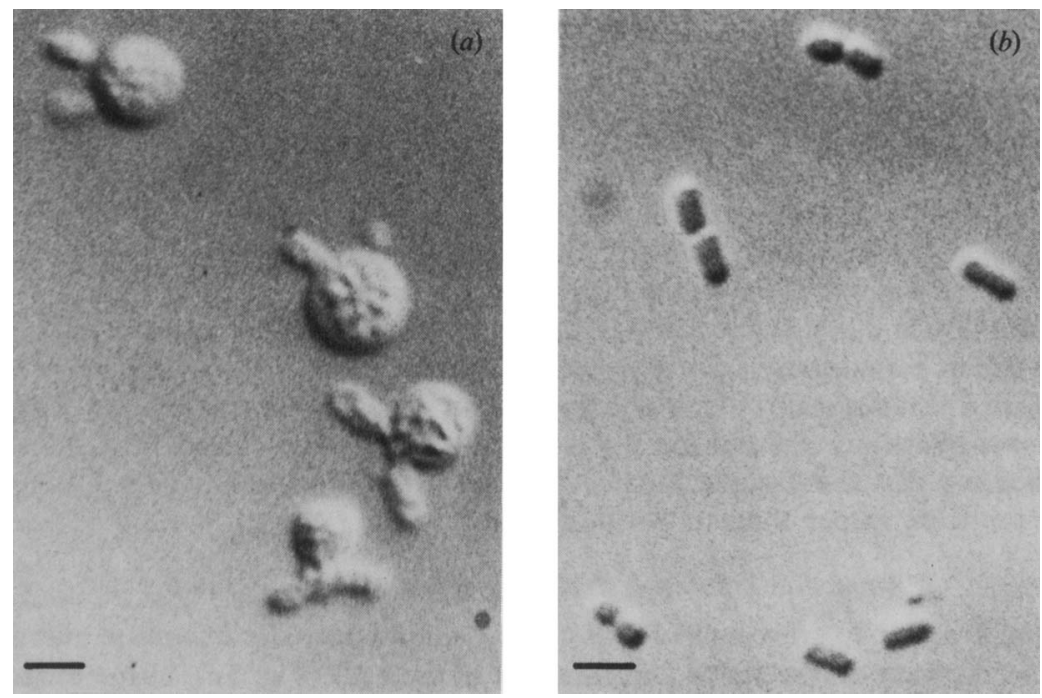

Fig. 5. Effect of ampicillin on the cell integrity of growing (a) and $1 \mathrm{~h}$ pre-starved cultures of S14 (b). The pictures were taken $1 \mathrm{~h}$ after the addition of ampicillin. Bars, $2 \mu \mathrm{m}$.

the percentage of undigested murein was determined at appropriate intervals. It was demonstrated that the addition of $\mathrm{Cm}$ alone had no effect on murein degradation. To establish whether the resistance to lysis of non-growing cells was due to decreased activities of the peptidoglycan hydrolases, the digestion of peptidoglycan labelled during growth was compared 


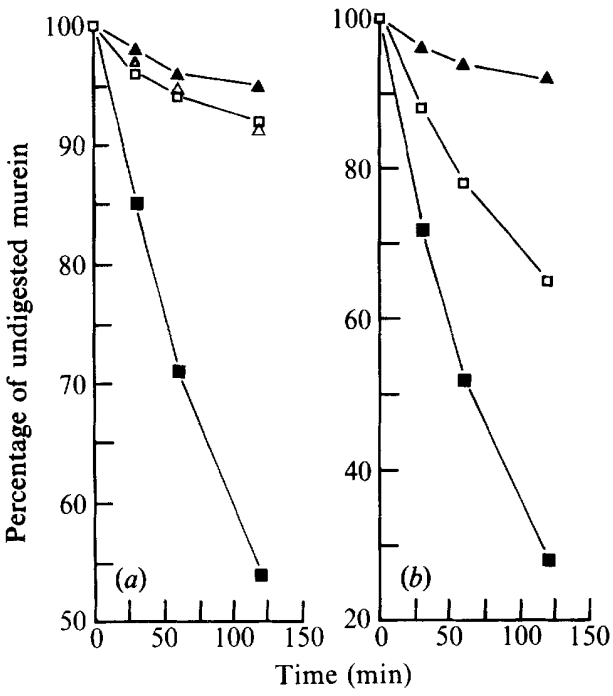

Fig. 6

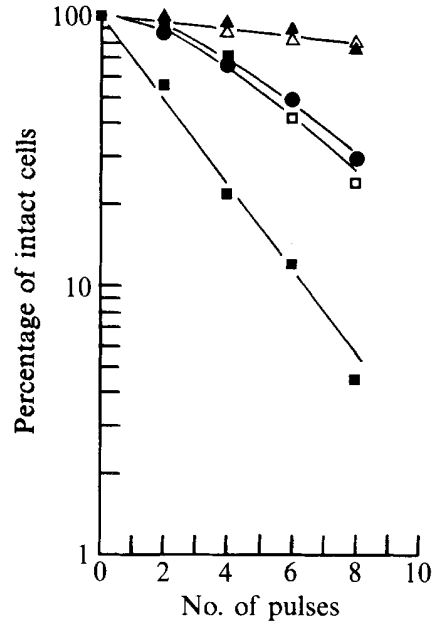

Fig. 7

Fig. 6. (a) Effect of chloramphenicol on the starvation-induced resistance to murein hydrolysis as measured by the solubilization of $\left[{ }^{3} \mathrm{H}\right]$ GlcNAc labelled murein during $1 \mathrm{~h}$ of starvation. At the onset of starvation the culture was divided into four portions: addition of ampicillin after $1 \mathrm{~h}$ of starvation ( $\square$ ), addition of ampicillin subsequent to pretreatment with chloramphenicol for $1 \mathrm{~h}$ in the starvation regime $(\square)$, control without additions $(\Delta)$, addition of chloramphenicol only $(\triangle)$. (b) Rate of ampicillin-induced hydrolysis of murein labelled with $\left[{ }^{3} \mathrm{H}\right] \mathrm{GlcN} A c$ during growth (squares) and during the initial phase of starvation (triangle), respectively. The digestion of murein labelled during growth was determined at the onset ( $\square$ ) and after $1 \mathrm{~h}$ of starvation ( $\square$ ). Digestion of murein labelled during starvation was determined after $1 \mathrm{~h}(\boldsymbol{\Delta})$. The percentage of undigested murein is plotted against the time of ampicillin incubation.

Fig. 7. Effect of starvation on lysis induced by sonication. The effect of repeated pulses of ultra-sound was determined for cells starved for $0 \mathrm{~h}(\square), 1 \mathrm{~h}(\square), 1 \mathrm{~h}$ with the addition chloramphenicol $(\bigcirc), 5 \mathrm{~h}$ $(\Delta)$ and $24 \mathrm{~h}(\triangle)$. The number of intact cells was determined microscopically.

with that labelled during the initial phase of fragmentation. The degree of murein digestion after $1 \mathrm{~h}$ starvation was more extensive in the peptidoglycan labelled during growth, while the murein labelled during the initial phase of starvation was essentially unaffected (Fig. 6b). This indicates an altered susceptibility to autolytic degradation in the 'new' portions of the murein rather than decreased activity of the murein hydrolases. However, the rate of degradation of 'old' cell wall was also influenced by the time of starvation. While old cell wall underwent extensive autolytic degradation at the onset of carbon and nutrient deprivation, the $1 \mathrm{~h}$ starved culture demonstrated a decreased rate of degradation (Fig. $6 b$ ).

\section{Resistance to lysis induced by sonication}

While ultra-sound treatment effectively promoted lysis of growing cells, the susceptibility to this treatment clearly diminished upon starvation (Fig. 7). In contrast to the resistance to Ap treatment, the resistance to sonication could not be abolished by the addition of $\mathrm{Cm}$ during the first hour of starvation (Fig. 7). Cm did not prevent incorporation of GlcNAc during this period (data not shown). The resistance to ultra-sound treatment may therefore be directly related to an increase in peptidoglycan per culture biomass. The amount of D-alanine in starved S14 cells has previously been analysed by gas chromatography/mass spectrometry (Malmcrona-Friberg et al., 1986). We recalculated the results presented by these authors and expressed the total amount of D-alanine per unit dry weight of the starvation suspension. During a $24 \mathrm{~h}$ starvation period, a twofold increase in the D-alanine content per unit dry weight was observed. 


\section{DISCUSSION}

The copiotrophic Vibrio S14 cells used in this study display a rapid increase in cell number with a concomitant size reduction during the first hours of energy and nutrient deprivation, which appears to be a common phenomenon of non-growing vibrios (Nyström et al., 1986; Amy et al., 1983; Baker et al., 1983). This cell division during non-growth, i.e. fragmentation (Novitsky \& Morita, 1977), involved both cell wall and DNA synthesis as well as an ongoing protein synthesis in S14 cells (Fig. 1). Inhibition of protein synthesis led to a cessation in cell division and DNA synthesis after approximately one doubling (Figs $1 \& 3$ ), indicating that ongoing rounds of replication terminate, but that no new rounds are initiated. Initiation of DNA replication requires proteins synthesized de novo (Lark et al., 1963; Schaechter, 1961; Messer, 1972). Inhibition of protein synthesis, either by the addition of chloramphenicol or by removing a required amino acid, leads to a cessation of DNA synthesis within 40-60 min in a growing culture of E. coli (Lark et al., 1963; von Meyenburg \& Hansen, 1987). The occurrence of cell division and DNA synthesis during starvation of S14 constitutes a marked distinction between this strain and the stress response of $E$. coli. No increase in cell number has been observed as a result of the transfer of rapidly growing $E$. coli $\left(2 \cdot 0\right.$ doublings $\left.\mathrm{h}^{-1}\right)$ to a starvation menstruum (unpublished observations). Cell division of $E$. coli during starvation may be negatively controlled by ppGpp, an effector of the stringent control regulon (Donachie et al., 1984). In addition, initiation of chromosome replication appears to be strictly coupled to growth of the E. coli cell (von Meyenburg \& Hansen, 1987) and initiation may be envisioned to start either when the ratio of a hypothetical inhibitor of replication to the cell volume has decreased to a critical level (Pritchard et al., 1969), or when sufficient amounts of an initiator have been accumulated (Sompayrac \& Maaløe, 1973). The division and initiation of replication of the S14 cells during the initial phase of starvation, however, occur during a period of net decrease in culture biomass (Nyström et al., 1986). Pierucci \& Helmstetter (1969) observed that a constant period of approximately $40 \mathrm{~min}$ of protein synthesis is required before division in $E$. coli cells. This period is growth-dependent and correlated with an increase in cell length (Donachie \& Robinson, 1987). In contrast, Vibrio S14 appears to initiate replication and division in the absence of growth and increase in cell length. The number of daughter cells produced during starvation, however, is correlated to the cell size and appears to be limited by the theoretical minimal cell volume ( $V_{\mathrm{u}}$, Donachie \& Robinson, 1987). The cell volume as a function of growth rate was determined for $\mathrm{S} 14$ cells incubated in a number of different media and the cell volume at zero growth rate $\left(V_{\mathrm{u}}\right)$ was found to be $0.5 \mu \mathrm{m}^{3}$ (Table 1). S14 cells grown at rates resulting in a cell size less than $2 V_{\mathrm{u}}\left(1.0 \mu \mathrm{m}^{3}\right)$ did not divide when transferred to a starvation menstruum and cells growing with a median cell volume of $1.2 \mu \mathrm{m}^{3}$ increased only 1.9 times during energy and nutrient deprivation. Furthermore, at the end of the fragmentation process, the daughter cells that were produced were not smaller than the theoretical minimal cell volume. The prolonged starvation survival process subsequent to cessation of fragmentation (in this study $6 \mathrm{~h}$ ) includes, however, a continued size reduction of the individual cell, as a result of degradation of endogenous material. This results in cells that are smaller than $V_{\mathrm{u}}$ (Morita, 1982; Nyström \& Kjelleberg, 1987).

At the onset of energy and nutrient deprivation the rate of murein synthesis markedly decreased during the first $30 \mathrm{~min}$, indicative of a stringent-control-like response (Tuomanen \& Tomasz, 1986), prior to an increase and a second phase of relatively high levels of synthesis (Fig. 2). The high level of synthesis was maintained throughout the fragmentation process. This was concomitant with an increase in the amount of D-alanine per unit cellular dry weight. It is possible that an increase in the cell wall/dry weight ratio is reflected by the increased resistance to sonication-induced lysis (Fig. 7). Furthermore, starvation caused a rapid and progressive increase in the resistance to Ap-induced lysis of the cells. The resistance of starved cells to the lysis-inducing agent, Ap, could be overcome by simultaneous treatment with chloramphenicol (Fig. $6 a$ ). The presence of a sequential induction of starvation proteins has previously been demonstrated for the Vibrio sp. S14 (Nyström et al., 1988), and blockage of protein synthesis during the first hours of starvation greatly compromised survival during prolonged starvation, while inhibition of protein synthesis subsequent to $4 \mathrm{~h}$ of starvation had no effect on viability 
Table 1. Cell volume as a function of growth rate and the total increase in cell number during subsequent starvation

Cells of Vibrio sp. S14 were grown at different rates in a series of different media. The cells were maintained in exponential growth by frequent dilution of the cultures into fresh medium and the cell volumes were determined for mid-exponential phase cells at each growth rate. The cell volume at zero growth rate $\left(V_{v}\right)$ was obtained from a stationary phase culture in MNSS. VNSS is a complex medium described previously (Nyström et al., 1986).

\begin{tabular}{lccc}
\multicolumn{1}{c}{ Growth medium } & $\begin{array}{c}\text { Growth rate } \\
\left(\text { doublings } \mathrm{h}^{-1}\right)\end{array}$ & $\begin{array}{c}\text { Median } \\
\text { cell volume } \\
\left(\mu \mathrm{m}^{3}\right)\end{array}$ & $\begin{array}{c}\text { Increase in cell } \\
\text { number during } \\
\text { subsequent starvation } \\
(\%)\end{array}$ \\
VNSS & $2 \cdot 2$ & $2 \cdot 6$ & 300 \\
MNSS plus Cas $\dagger$ & $1 \cdot 8$ & $2 \cdot 3$ & 290 \\
MNSS plus Cas minus Glc* & $1 \cdot 5$ & $1 \cdot 8$ & 170 \\
MNSS & $1 \cdot 1$ & $1 \cdot 2$ & 90 \\
MNSS minus Glc plus Man ${ }^{*}$ & $0 \cdot 4$ & $0 \cdot 7$ & 0 \\
MNSS plus Cas (stationary phase) & $0 \cdot 0$ & $0 \cdot 5\left(V_{\mathrm{u}}\right)$ & 0
\end{tabular}

(unpublished results). It seems plausible that some of the proteins belonging to an initial temporal class of starvation proteins play a crucial role in maintaining cell integrity and making the cells less susceptible to autolysis. The diminished rate of lysis of Ap-treated starved cells could be due either to changes in the murein, making it resistant to the murein hydrolases, or to a decreased activity of the hydrolases. To determine whether the murein of non-growing cells was degraded at an altered rate due to a decreased activity of the hydrolases, murein degradation after $1 \mathrm{~h}$ starvation was determined by using peptidoglycan that was radiolabelled in both growing and starved cells, respectively. When compared with peptidoglycan of growing cells (35\% release after $2 \mathrm{~h} \mathrm{Ap}$ treatment), peptidoglycan radiolabelled during $1 \mathrm{~h}$ of starvation released only $6 \%$ (Fig. $6 \mathrm{~b}$ ). Thus the rapid development of resistance against the lytic effects of Ap during starvation cannot only be explained by a decline in the murein hydrolase activity. The progressively decreasing rate of murein degradation of the 'old' murein during starvation (Fig. $6 \mathrm{~b}$ ) could be due to redistribution of the label away from the equatorial area of the cells. The incorporation of radiolabel is suggested to occur at topographically limited areas (Ryter et al., 1973; Tuomanen, 1986) and autolysis is suggested to be initiated at these areas, which are associated with the septum (Tuomanen, 1986) (Fig. 5a).

Adaptation of $\mathrm{S} 14$ cells to starvation involves the induction of starvation-specific proteins as well as proteins overlapping with those induced by other stresses (Nyström et al., 1988). We suggest that starvation-related proteins can be divided into at least two categories: one directly involved in conferring maintenance and integrity of the cells, and the other relating to the cells' recovery from starvation when confronted with favourable conditions for regrowth. Mårdén $e t$ al. (1987) showed that proteins involved in high- and low-affinity transport systems were differently modulated during starvation and recent studies in our laboratory have demonstrated a starvation-related production of exoproteases, which appears to be positively regulated by the signal molecule cAMP (N. Albertson personal communication). The proteins involved in autolysis resistance, however, would belong to the first category, making the starved cells resistant to the deleterious effects of the activity of autolytic enzymes during non-growth. How these proteins are regulated and what the identities of these proteins are need further investigation. Towards this goal we have constructed a series of Mu directed lac operon fusion mutants of S14, which is being analysed with respect to impaired starvation survival characteristics and starvation-induced autolysis resistance.

We thank Paul Cohen and Nan Albertson for helpful discussions. This study was supported by a grant from the Swedish Science Research Council. 


\section{REFERENCES}

Amy, P. S., Pauling, C. \& Morita, R. Y. (1983). Starvation-survival processes of a marine Vibrio. Applied and Environmental Microbiology 45, 17481752.

Baker, R. M., Singleton, C. \& Hood, M. A. (1983). Effects of nutrient deprivation on Vibrio cholerae. Applied and Environmental Microbiology 46, 930-940.

Donachie, W. D. \& Robinson, A. C. (1987). Cell division: Parameter values and the process. In Escherichia coli and Salmonella typhimurium: Cellular and Molecular Biology, vol. 2, pp. 1578-1593. Edited by F. C. Neidhart. Washington D.C.: American Society for Microbiology.

Donachie, W. D., Begg, K. J. \& Sullivan, N. (1984). Morphogenes of Escherichia coli. In Microbial Development, pp. 27-62. Edited by R. Losick \& L. Shapiro. Cold Spring Harbor, NY: Cold Spring Harbor Laboratory.

Goodell, W. \& Tomasz, A. (1980). Alteration of Escherichia coli murein during amino acid starvation. Journal of Bacteriology 14, 1009-1016.

KUSSER, W. \& ISHIGURO, E. E. (1985). Involvement of the relA gene in the autolysis of Escherichia coli induced by inhibitors of peptidoglycan biosynthesis. Journal of Bacteriology 164, 861-865.

LARK, K. G., RePKo, T. \& Hoffman, E. J. (1963). The effect of amino acid deprivation on subsequent deoxyribonucleic acid replication. Biochimica et biophysica acta 76, 9-24.

Malmcrona-Friberg, K., Tunlid, A., MÅrdén, P., KJelleberG, S. \& ODHAM, G. (1986). Chemical changes in cell envelope and poly- $\beta$-hydroxybutyrate during short term starvation of a marine bacterial isolate. Archives of Microbiology 144, 340-345.

MÅrdén, P., NySTRÖM, T. \& KJELleberG, S. (1987). Uptake of leucine by a marine gram-negative heterotrophic bacterium during exposure to starvation conditions. FEMS Microbiology Ecology 45, 233-241.

MÅrdÉn, P., Tunlid, A., MalmCrona-Friberg, K., Odham, G. \& KJelleberg, S. (1985). Physiological and morphological changes during short term starvation of marine bacterial isolates. Archives of Microbiology 142, 326-332.

MÅrdén, P., Hermansson, M. \& KJelleberg, S. (1988). Incorporation of tritiated thymidine by marine bacterial isolates when undergoing a starvation survival response. Archives of Microbiology 149, $427-432$.

MESSER, W. (1972). Initiation of deoxyribonucleic acid replication in Escherichia coli $\mathrm{B} / \mathrm{r}$ : chronology of events and transcriptional control of initiation. Journal of Bacteriology 112, 7-12.

von Meyenburg, K. \& Hansen, F. G. (1987). Regulation of chromosome replication. In Escherichia coli and Salmonella typhimurium: Cellular and Molecular Biology, vol. 2, pp. 1555-1577. Edited by F. C. Neidhardt. Washington, DC: American Society for Microbiology.
MoRITA, R. Y. (1982). Starvation survival of heterotrophs in the marine environment. In Advances in Microbial Ecology, vol. 6. pp. 171-198. Edited by K. C. Marshall. New York: Plenum Press.

MoRiTA, R. Y. (1985). Starvation and miniaturisation of heterotrophs, with special emphasis on maintenance of the starved viable state. In Bacteria in Their Natural Environments, pp. 111-130. Edited by M. M. Fletcher \& G. D. Floodgate. London: Academic Press.

Novitsky, J. A. \& MoRITA, R. Y. (1977). Survival of psycrophilic marine Vibrio under long term nutrient starvation. Applied and Environmental Microbiology 33, 635-641.

NySTRÖM, T. \& KJELlebERG, S. (1987). The effect of cadmium on starved heterotrophic bacteria isolated from marine waters. FEMS Microbiology Ecology 45, 143-153.

Nyström, T., MÅRdÉN, P. \& KJelleberG, S. (1986). Relative changes in incorporation rates of leucine and methionine during starvation survival of two bacteria isolated from marine waters. FEMS Microbiology Ecology 38, 285-292.

Nyström, T., Albertson, N. \& KJelleberg, S. (1988). Synthesis of membrane and periplasmic proteins during starvation of a marine Vibrio sp. Journal of General Microbiology 134, 1645-1651.

Pierucci, O. \& Helmstetter, C. E. (1969). Chromosome replication, protein synthesis and cell division in Escherichia coli. Federation Proceedings 28, 17551760.

Pritchard, R. H., Barth, P. T. \& Collins, J. (1969). Control of DNA synthesis in bacteria. London: Symposia of the Society for General Microbiology 19, 263-297.

RYTER, A., Hirota, Y. \& Schwarz, U. (1973). Process of cellular division in Escherichia coli: growth pattern of E. coli murein. Journal of Molecular Biology 78, 185-195.

SCHAECHTER, M. (1961). Patterns of cellular control during unbalanced growth. Cold Spring Harbor, NY: Cold Spring Harbor Symposia on Quantitative Biology 26, pp. 53-62.

Sompayrac, L. \& MaAløe, O. (1973). Autorepressor model for control of DNA replication. Nature, London 241, 133-135.

TuOManen, E. (1986). Newly made enzymes determine ongoing cell wall synthesis and the antibacterial effects of cell wall synthesis inhibitors. Journal of Bacteriology 167, 535-543.

TuOManen, E. \& Tomasz, A. (1986). Induction of autolysis in nongrowing Escherichia coli. Journal of Bacteriology 167, 1077-1080.

Tuomanen, E., Markiewicz, Z. \& Tomasz, A. (1988). Autolysis-resistant peptidoglycan of anomalous composition in amino acid starved Escherichia coli. Journal of Bacteriology 170, 1373-1376. 